\author{
Alexander Parmee \\ Uniwersytet Łódzki \\ acparmee1990@gmail.com
}

\title{
Szkocja na rozdrożu politycznym
}

Streszczenie: Autor w swojej pracy przedstawia relacje między Szkocją a Anglią. Próbuje wyjaśnić jak partia Alexa Salmonda NSP (National Scottish Party) uzyskała większość w Parlamencie Szkockim. Bada różne aspekty historyczne, ekonomiczne, polityczne i społeczne, które mogą mieć wpływ na wyjście Szkocji z Zjednoczonego Królestwa. Ponadto, stara się przewidzieć konsekwencje, które nastąpiłyby po wygraniu referendum przez zwolenników secesji czyli: jaką walutę Szkocja mogłaby przyjąć; w jaki sposób zabezpieczyłaby swój rozwój ekonomiczny? Czy musiałaby jeszcze raz aplikować do różnych organizacji międzynarodowych jak np.: NATO czy UE? Autor analizuje wypowiedzi premiera Wielkiej Brytanii Davida Camerona oraz premiera Szkocji Alexa Salmonda w celu ukazania ich głównych argumentów za lub przeciw referendum.

Od ponad 300 lat Szkocja jest w Unii Realnej z Anglią. Choć Szkocja w obecnej chwili posiada własny parlament (tzw. Home rule) to ma on małe kompetencje w sprawach finansowych czy polityki zagranicznej. Najważniejsze decyzje podejmowane w sprawie całej Wielkiej Brytanii zapadają w Westminsterze (parlament Zjednoczonego Królestwa Wielkiej Brytanii oraz Irlandii Północnej), dlatego też trudno się dziwić, że po zdobyciu władzy przez Narodową Partię Szkocji (SNP - Scottish National Party) jej lider Alex Salmond ogłosił, że chce referendum w sprawie niepodległości Szkocji. 15 października 2012 roku Salmond i Cameron podpisali „Edinburgh agreement". Akt ten pozwala na przeprowadzenie przez parlament szkocki legalnego referendum w sprawie niepodległości Szkocji. Jest to kluczowy moment dla Szkotów w ich historii ponieważ byli oni związani politycznie, ekonomicznie i kulturowo z Wielką Brytanią ponad 300 lat. Według obliczeń przedstawionych przez gazetę The Guardian około jedna trzecia Szkotów chce pełnej niepodległości oraz wystąpienia z Wielkiej 
Brytanii, pozostałą część Szkotów można uznać za niezdecydowanych lub popierających unię między państwami. Ponadto wiadomo już, że szef SNP przeprowadzi referendum w 2014 roku. Obietnice niepodległości Szkocji przez SNP wydawały się utopią w 2007 roku, nikt z angielskich polityków nie wyobrażał sobie, że Szkocja stanie przed tym wyborem tak szybko. Referendum zakłada proste pytanie: „Czy chcesz żeby Szkocja była niepodległa?” na które można odpowiedzieć tak lub nie.

Jednak wiele Szkotów zdaje sobie sprawę, że kuszące obietnice Alexa Salmonda o niepodległości Szkocji wiążą się z poważnymi konsekwencjami ekonomicznymi, politycznymi oraz socjalnymi. Mnożą się pytania na temat przyszłości Szkocji gdyby uzyskała niepodległość. Jaką walutę przyjmie? Co z ropą na morzu północnym? Czy automatycznie stanie się członkiem Unii Europejskiej? Czym zastąpić NHS (National Health Sernice - opieka zdrowotna w całej Wielkiej Brytanii) i skąd wziąć pieniądze? Alex Salmond stara się unikać prostych odpowiedzi na te pytania ponieważ wie, że społeczna debata nad tymi pytaniami mogłaby źle wpłynąć na wyniki referendum, zamiast tego stara się wskrzesić patriotyzm u swoich rodaków poprzez ducha Bannockburn (nazwa pochodzi od rzeki, koło której Szkoci pod przewodnictwem Roberta Bruce wygrali z Anglikami bitwę). Odpowiedzi na niektóre pytania należy szukać w historii między Szkocją a Anglią.

Aby lepiej zrozumieć złożoność relacji szkocko-angielskich należy zanalizować historyczne relacje pomiędzy nimi. Szkoci od zawsze byli narodem wojowniczym, który dążył do pełnej niezależności. Ich tereny były trudne do podbicia ponieważ Szkocja jest położona na terenach górzystych, dlatego też Anglicy mieli trudności z pokonaniem Szkotów. Oprócz tego wywodzący się z plemion celtyckich Szkoci mieli charyzmatycznych przywódców, którzy byli też dobrymi strategami. Dobrym przykładem może być Robert Bruce, który pokonał króla Anglii Edwarda II w bitwie pod Bannockburn w 1314 roku. Jednak pomimo to, niezależność Szkocji od swoich południowych sąsiadów zaczęła stopniowo słabnąć. Szkoci zostali pokonani w 1513 roku w bitwie pod Flodden, a następnie obydwa kraje zostały połączone przez Unię Personalną w 1603 r. w osobie króla Szkocji i Anglii Jakuba I Stuarta. Następnie w 1707 roku wzmocniono więzy między Anglią a Szkocją poprzez podpisanie Aktu o Unii (Act of Union). Dekret ten zapewniał Anglii korzyści polityczne, a Szkocji gospodarcze. Postanowiono, że Szkocja zrezygnuje ze swojego parlamentu na rzecz Parlamentu Angielskiego, gdzie Szkocja miała być reprezentowana przez 16 parów i 45 posłów, jednocześnie zachowując odrębność kulturalną, religijną oraz instytucjonalną. Warto, też wspomnieć, że Szkocja uzyskała przywilej wolnego handlu z Anglią. Akt o Unii z 1707 roku pozwolił zepchnąć na bok antagonizmy dzielące te kraje na rzecz rozwoju gospodarczego oraz wspólnej polityki zagranicznej (Trevelyan, 1973: 572). Jednak to Anglia kierowała gospodarką 
oraz podejmowała ważne decyzje polityczne, dlatego też większość elity szkockiej przyjęła za swój cel stworzenie legislatywy szkockiej, która byłaby niezależna od parlamentu w Londynie $\mathrm{w}$ ważnych kwestiach dotyczących Szkocji. W tym samym czasie również inne narody wchodzące w skład Wielkiej Brytanii chciały rozszerzenia swoich praw.

W XIX w. Irlandczycy zaczęli się domagać poszerzenia swojej autonomii względem rządu Jej Królewskiej Mości. Szkoci wykorzystali tę sytuację formułując własne postulaty rozszerzenia autonomii wobec Londynu. Pierwszym przejawem zainteresowania się Szkocją i jej problemami ze strony brytyjskiego rządu było stworzenie Narodowego Związku Windykacji Praw Szkocji przez Partię Konserwatystów. Organ ten nie miał żadnej mocy legislacyjnej, lecz był pierwszą próbą skupienia się rządu brytyjskiego na problemach Szkocji. W następnych latach potrzeba poszerzenia autonomii w Szkocji rosła, dlatego też premier Anglii William Edward Gladstone na zjeździe mającym miejsce w Aberdeen w 1871 r. stwierdził, że jeśli Irlandia miała by mieć autonomię to również Szkocja ją dostanie. Po wejściu Irlandzkiego "Home Rule Bill” Gladstone w 1885 roku utworzył stanowisko Sekretarza Stanu ds. Szkocji (obecnie jest nim Michael Moore). Jednak Szkoci nie dostali większej autonomii w postaci własnego rządu, gdyż u władzy byli konserwatyści, których celem było umocnienie Unii między Szkocją a Anglią. Utworzenie własnego autonomicznego parlamentu przez Szkotów byłoby dla konserwatystów porażką polityczną nawet jeśli jurysdykcja takiego organu ograniczyłaby się do spraw wewnętrznych. Kwestia zwiększenia autonomii dla Szkotów została znowu poruszona, gdy w Parlamencie Angielskim do władzy doszedł liberalny rząd w 1905 roku. W 1913 roku w Westminsterze została przedstawiona ustawa "Scottish Home Rule Bill", która miała stworzyć autonomiczny rząd Szkocji. Jednak proces legislacyjny został zatrzymany przez wybuch I Wojny Światowej. Warto wspomnieć, że tendencje separatystyczne wśród Brytyjczyków zanikają gdy istnieje zagrożenie z zewnątrz, dlatego też kwestia stworzenia odrębnej konstytuanty dla Szkocji została odłożona na bok podczas I Wojny Światowej.

W latach dwudziestych XX wieku powstało wiele partii nacjonalistycznych, które popierały dążenie Szkocji do niepodległości. W 1920 powstała Szkocka Narodowa Liga, która została wchłonięta przez Narodową Partię Szkocji, a ta przez SNP (Scottish National Party) w 1934 roku. SNP wpierw postulowała stworzenie zgromadzenia narodowego Szkocji pod flagą Wielkiej Brytanii, jednak szybko zmieniła ten postulat na całkowitą niezależności od Anglii. Następnie w latach 40 i 50 poparcie dla SNP spadło z powodu wybuchu II Wojny Światowej. Dopiero w latach 70 po sukcesie SNP w wyborach lokalnych z 1974 roku, pomysł stworzenia Zgromadzenia Narodowego Szkocji powrócił. Następstwem tego było poparcie "Scotland 
Act" przez rząd laburzystów w 1978 roku, ustawa ta gwarantowała utworzenie zgromadzenia narodowego w Szkocji na czele której stałby „Pierwszy Sekretarz" przejmując kompetencje należące do Sekretarza Stanu ds. Szkocji. Ponadto Zgromadzenie Narodowe Szkocji mogło by decydować w sprawach: edukacji, środowiska, zdrowia, spraw wewnętrznych oraz usług socjalnych. „Scotland Act” nie został jednak zaakceptowany przez rząd brytyjski z powodu wewnętrznego podziału laburzystów. Nie mogli uzgodnić między sobą jak duże kompetencje powinien mieć przyszły rząd Szkocji. Po wygraniu wyborów do Westminsteru przez konserwatystów w roku 1979, sprawa utworzenia Zgromadzenia Narodowego Szkocji pozostała w cieniu aż do roku 1997, kiedy do władzy powrócił rząd laburzystów. Lider laburzystów Tony Blair zarządził referendum w Szkocji składające się z dwóch pytań: „Czy zgadzasz się, że powinien powstać Szkocki Parlament” oraz „Czy zgadzasz się, aby Szkocki Parlament miał uprawnienia do nakładania podatków". Na pierwsze pytanie $74,3 \%$ wyborców odpowiedziało „tak", natomiast na drugie pytanie pozytywnie zagłosowało 63,5\% elektoratu. Następstwem pozytywnego wyniku referendum było zatwierdzenie przez rząd brytyjski „Scotland Act” w 1998 roku. Ustawa ta pozwalała na utworzenie parlamentu w Szkocji. Wybory do parlamentu odbyły się 6 maja w 1999 roku. Następnie tego samego roku w lipcu władza ustawodawcza została przeniesiona $\mathrm{z}$ Westminsteru do Holyrood (siedziba szkockiego parlamentu).

Obecnie w parlamencie Szkocji większość ma SNP, aż 68 mandatów na 129. Do kompetencji rządu Szkocji na mocy „Scotland Act” należy: edukacja, zdrowie oraz agroturystyka. Oprócz tego parlament Szkocji ma ograniczone uprawnienia do zmieniania podatku. W powyżej wymienione kompetencje Holyroodu rząd Brytyjski nie ingeruje. Natomiast w sprawach: polityki zagranicznej, gazu, ropy, elektryczności, węgla, Unii Europejskiej, systemu monetarnego, rząd Szkocji nie ma żadnej mocy legislacyjnej. Z tego właśnie powodu SNP osiągnęła tak dobry rezultat na czele z Alexem Salmondem, który zadał bardzo trudne pytanie dla rządu w Londynie: „Dlaczego Szkoci nie mają prawa decydować o złożach ropy leżących na dnie Morza Północnego koło Szkocji"? Przewiduje się, że w ciągu 6 lat złoża ropy na Morzu Północnym przyniosą przychód o wartości łącznej 56 miliardów GBP (www.theguardian.com: 2013-04-28). Alex Salmond stwierdził, że gdyby Szkocja uzyskała niepodległość to 90 procent złóż ropy naftowej z Morza Północnego należałoby do Szkocji, wtedy główny argument zwolenników unii: „Szkocja jest zbyt słaba aby być niepodległa” straciłby na znaczeniu z momentem uzyskania dostępu przez Szkocje do tychże złóż ropy.

SNP chce aby referendum odbyło się pod koniec 2014 roku, natomiast Partia Konserwatywna, która sprawuje władzę w Westminsterze na obecną chwilę chce, aby referendum odbyło się wcześniej. Warto dodać, że w 2014 roku upływa rocznica historycznego zwycięstwa Szkotów nad Anglikami 
w bitwie pod Bannockburn w 1314 roku. Alex Salmond liczy na wzrost patriotyzmu podczas obchodów 700 rocznicy pokonania Anglików oraz na wzrost tendencji separatystycznej wśród Szkotów. Premier Wielkiej Brytanii David Cameron (stojący na czele Partii Konserwatywnej w Westminsterze) próbował przyspieszyć referendum używając argumentu, że niepewna przyszłości Szkocji źle wpływa na inwestorów i gospodarkę całej Wielkiej Brytanii (www.polemi.co.uk: 2013-04-11). Lider Partii Konserwatywnej chciał wywrzeć presję polityczną na Salmondzie, aby ten rozpisał referendum przed 2014 ponieważ zdawał sobie sprawę z tego, że poparcie dla niezależnej Szkocji w obecnej chwili wynosi tylko 34 procent. Taki wynik byłby za mały gdyby tylko połowa z uprawnionych do głosowania wzięłaby udział w referendum. Jednak Pierwszy Minister Szkocji chce, aby referendum odbyło się później, ponieważ da mu to czas na przekonanie Szkotów, którzy nie są zdecydowani czy być za czy przeciw. Ponadto Salmond pragnie, aby prawa wyborcze dostali wszyscy obywatele powyżej 16 roku życia.

Pierwszy Minister Szkocji odniósł duży sukces w listopadzie 2012 roku podczas spotkania z Davidem Cameronem. Ustalono wtedy, że referendum odbędzie się 18 września w 2014 roku, ponadto zdecydowano, że wiek wyborczy zostanie obniżony tak aby 16 szesnastoletni i siedemnastoletni wyborcy mogli zdecydować o przyszłości Szkocji (zostało to potwierdzone 17 czerwca 2013 roku przez ustawę przyjętą przez Holyrood). Oprócz tego porzucono plan „devo-max" (czyli rozszerzenie kompetencji Holyroodu bez pełnej niepodległości Szkocji) na rzecz prostego pytania „Czy zgadzasz, że Szkocja powinna być niepodległym państwem?” (www.scotreferendum.com/ blog: 2013-07-28).

Warto zwrócić uwagę, że tak postawione pytanie nie wspomina o rozpadzie Zjednoczonego Królestwa. Dla Wielkiej Brytanii byłby to kłopot natury politycznej, ponieważ takie państwa jak Rosja mogłyby zakwestionować jej udział w Radzie Bezpieczeństwa ONZ. Czy po odłączeniu Szkocji od Wielkiej Brytanii w sensie prawa międzynarodowego Zjednoczone Królestwo byłoby innym państwem? W teorii można odpowiedzieć, że nie powołując się na przypadek ZSRR, który przekształcił się w Federacje Rosyjską w latach 90, która nie była już aglomeratem państw socjalistycznych. Natomiast dla Szkocji problem utworzenia nowego państwa byłby natury ekonomicznej i politycznej. Z jednej strony Szkocja ponownie musiała by przejść przez proces akcesji do Unii Europejskiej. Herman Van Rompuy, Prezydent Rady Europy oraz José Manuel Barroso, Prezydent Komisji Europejskiej stwierdzili, że Szkocja musiałaby ponownie złożyć wniosek o przystąpienie do Unii Europejskiej. Ponadto Hiszpania i Cypr zapowiedziały weto, gdyby Szkocja chciała wejść do UE. Hiszpania, która sama boryka się z paroma regionami, które dążą do niepodległości (Katalonia 
i Kraj Basków) jest naturalnym sojusznikiem Wielkiej Brytanii w zwalczaniu ruchów separatystycznych. Salmond jednak uważa, że akcesja Szkocji do Unii Europejskiej to kwestia czasu i członkom Wspólnoty nie opłaca się blokować jej wejścia. ponieważ jest to strata cennego czasu (www.scotland. gov.uk: 2013-07-29).

Warto wspomnieć, że gdyby Szkocja uzyskałaby niepodległość to musiałaby zdecydować się na jakąś walutę. Pierwszą opcją mogło by być euro, choć w obecnym stanie dołączanie jakiegokolwiek kraju do strefy euro nie wygląda korzystnie. Innym wyjściem mogłoby by być przyjęcie funta szterlinga co wiązałoby się z uzależnieniem gospodarki Szkocji od The City (centrum finansowego Anglii). Istnieje też możliwość stworzenia nowej waluty, jednak tutaj wiązałoby się to $\mathrm{z}$ ryzykiem inflacji, co prawdopodobnie odstraszyłoby inwestorów w kraju.

Sondaże zrobione w 2011 roku pokazują, że większość Szkotów chce poszerzenia kompetencji parlamentu Szkocji, natomiast nie chce jej wyjścia z Wielkiej Brytanii. Paradoksalnie większość Anglików chce, aby Szkocja się odłączyła. Jest to spowodowane tym, że Szkoci w odróżnieniu od Anglików nie płacą podatków za opiekę zdrowotną oraz za edukację wyższą. Gdyby jednak Szkoci zagłosowali za wyjściem z Wielkiej Brytanii to proces ten trwałby parę lat, ponieważ wiele kwestii ekonomicznych, finansowych i militarnych musiałoby być wcześniej rozwiązanych. W centrum dyskusji znalazłby się bazy wojenne na wyspie Clyde, gdzie stacjonują statki podwodne z bronią nuklearną. Pierwszy Minister Szkocji stwierdził, że Szkocja nadal uważałby Elżbietę II za głowę państwa. Gdyby jednak Szkoci opowiedzieli się za zostaniem w Unii z Anglią to referendum nie zostało by powtórzone w najbliższych latach. Alex Salmond stwierdził, że takie referendum odbywa się raz na pokolenie. To podkreśla jego ważność.

Od momentu ogłoszenia dokładnej daty referendum zarówno SNP, jak i rząd w Londynie, prowadzą kampanie mające na celu przekonanie niezdecydowanych wyborców do opowiedzenia się na „tak” lub „nie” w kwestii niepodległości Szkocji. Alex Salmond stara się ukazać swoją wizję niepodległej Szkocji podczas różnych spotkań z wyborcami. Porusza on główne tematy takie jak: członkostwo $\mathrm{w}$ organizacjach międzynarodowych po uzyskaniu niepodległości przez Szkocję, waluta, kwestia broni nuklearnej oraz ropy naftowej na Morzu Północnym. W jego opinii niepodległa Szkocja zwiększyłaby wydatki na okręty wojskowe, które miałby za zadanie patrolować linie brzegową Szkocji1. Ponadto Pierwszy Minister stwierdził w swojej wypowiedzi publicznej podczas konferencji w Shetlandach, że broń nuklearna na wyspie Clyde nie miałaby racji bytu po uzyskaniu niepodległości Szkocji, ponieważ znajduje się zbyt blisko jednego z większych

${ }^{1}$ Warto dodać, że linia brzegowa Szkocji jest dłuższa od linii brzegowej Indii. 
miast w Szkocji ${ }^{2}$. Tym samym sprzeciwia się on utrzymywaniu drogiego systemu Trident ${ }^{3}$ przez Szkocję (www.soundcloud.com/scotgov/publicdiscussion-shetland: 2013-07-28). Jednak rząd Camerona nie planuje przeniesienia tego systemu poza granice Szkocji, ponieważ koszta tego przedsięwzięcia byłyby astronomiczne. Rozwiązanie tej kwestii nie będzie łatwe, ani szybkie.

Modelem politycznym i ekonomicznym dla Salmonda jest Norwegia. To małe państwo posiadające zaledwie 5 miliardów ludzi jest w stanie stworzyć doskonałe warunki do rozwoju gospodarczego, dzięki „czarnemu złotu" czyli ropie naftowej, dlatego też SNP uważa za swój priorytet uzyskanie jak największej ilości złóż należących terytorialnie do Szkocji. Na stronie internetowej www.scotreferendum.com utworzonej przez SNP znajdują się szczegółowo rozpisane projekty poszczególnych sektorów gospodarki i polityki niepodległej Szkocji. W detalach został opisany sektor wydobycia ropy i gazu, według wstępnych obliczeń Szkocja byłaby w stanie wydobywać 6 razy więcej ropy od własnego zapotrzebowania na ten surowiec, dlatego też sprzedaż „czarnego złota” miała być duży wpływ na budżet. Ponadto, partia Salmonda argumentuje, że przyszły rząd niepodległej Szkocji byłby w stanie stworzyć lepsze warunki niż rząd w Londynie, który ściąga ogromne podatki od inwestorów działających na Morzu Północnym. Oprócz tego Szkocja posiada już wyszkoloną kadrę w dziedzinie wydobywania ropy naftowej. Szacuje się, że około 220 tys. osób w Szkocji jest w tej chwili zatrudnionych $\mathrm{w}$ tym sektorze ${ }^{4}$. Alex Salmond uważa, że gdyby Szkocja dostała taki udział w ropie naftowej, jaki jej się należy to mogłaby wykonać podobny skok w gospodarce jak Norwegia 5 .

W tym miejscu należy zadać sobie pytanie: w jaki sposób zostaną podzielone złoża między Anglią a Szkocją. Jednym z pomysłów, jest podzielenie złóż według czynnika geograficznego. Zwolennikiem tego pomysłu jest Pierwszy Minister Szkocji, ponieważ przy takim podziale 90\% złóż przypadło by Szkotom. Innym pomysłem jest podzielenie złóż ropy naftowej według wskaźnika demograficznego, w tym przypadku tylko 9\% „czarnego

2 Wiadomo, że brytyjskie nuklearne łodzie podwodne stacjonują w bazie wojskowej na wyspach Clyde około $30 \mathrm{~km}$ od Glasgow.

${ }^{3}$ System Trident został zakupiony w latach 80 przez Margaret Thatcher a następnie aktualizowany przez następne rządy. Polegał on na ulokowaniu broni nuklearnej na statkach podwodnych, które bazowały na wspomnianych wcześniej wyspach Clyde. System ten był skierowany przeciwko ZSRR, który $\mathrm{w}$ tym samym czasie posiadał broń nuklearną na wschodzie Europy.

${ }^{4}$ www.scotland.gov.uk/Resource/0042/00428074.pdf: 2013-07-27.

5 W 1970 roku, PKB per capita w Norwegi wynosił 8,9\% niżej niż w Wielkiej Brytanii, natomiast w roku 2011 PKB per capita w Norwegi było większe o 71,5\% od Wielkiej Brytanii. 
złota" znajdującego się na dnie morza znalazło by się po stronie Szkocji. Dopóki Szkocja nie osiągnie pełnej niepodległości, dopóty kwestia ta będzie nierozwiązana.

Ważnym elementem kampanii „Yes” jest jasne postawienie sprawy przyszłej waluty oraz polityki fiskalnej w pełnili niepodległej Szkocji. Według raportu specjalnej grupy profesorów zajmujących się wyżej wymienioną problematyką, Szkocja może pójść w czterech różnych kierunkach jeśli chodzi o walutę: funt szterling (podobnie jak dolar Panamski), euro, własna waluta oraz funt szterling oparty na unii monetarnej (podobnej do strefy euro). Alex Salmond uważa, że najlepszą opcją dla niepodległej Szkocji byłoby przyjęcie funta szterlinga opartego na unii monetarnej z Zjednoczonym Królestwem. NSP argumentuje, że obydwa kraje od 300 są w unii i mają bardzo silne powiązania ekonomiczne ze sobą, ponadto mają podobną produktywność oraz PKB per capita 6 . Jednak warto zauważyć, że takie rozwiązanie byłoby podobne do unii monetarnej w UE, która w tej chwili przeżywa kryzys. Minister Finansów Wielkiej Brytanii George Osborone ostrzegł podczas jednych ze swoich konferencji, że unia monetarna dwóch oddzielnych i suwerennych państw nie jest tą samą unią między Szkocją a Wielką Brytanią jak w chwili obecnej. Stwierdza on, że Wielka Brytania byłaby bardziej narażona na kryzys ekonomiczny ze strony niepodległej Szkocji gdyby była z nią w unii monetarnej. Ponadto Minister Finansów Wielkiej Brytanii stwierdził, że kurs funta szterlinga mógłby być niestabilny z powodu dużej różnicy w eksporcie między obydwoma państwami ${ }^{7}$. Wybór ten nie jest łatwy - gdyby Szkocja uzyskała niepodległość to prawdopodobnie zostałaby przy funcie szterlingu $\mathrm{w}$ unii monetarnej z Wielką Brytanią.

Inną kwestią często poruszaną przez NSP i jego lidera Alexa Salmonda była przynależność do różnych organizacji. Według Pierwszego Ministra Szkocji jego kraj miałby za cel bycie „dobrym obywatelem świata” a nie jego liderem. W jego wizji Szkocja zajmuje pozycję małego kraju na arenie międzynarodowej, który tak jak Norwegia specjalizuje się w rozwiązywaniu konfliktu między zwaśnionymi stronami. Ponadto, Salmond uważa NATO za kluczowy filar polityki zagranicznej nowego państwa. Przy współpracy z innymi członkami NATO, jak Norwegia, Szkocja byłaby w stanie patrolować i chronić swoje tereny. Oprócz tego Pierwszy Minister w swoim przemówieniu w Waszyngtonie stwierdził, że Szkocja chciałaby kontynuować ścisłą współpracę z Stanami Zjednoczonymi.

Jeśli Szkocja zagłosuje za wyjściem z Wielkiej Brytanii i stanie się w pełni suwerennym państwem to szacuje się, że do 2016 zdoła zakończyć

\footnotetext{
${ }^{6}$ www.scotland.gov.uk/Resource/0042/00420804.pdf: 2013-08-11.

${ }^{7}$ www.theguardian.com: 2013-08-20.
} 
wszelkie negocjacje z Wielką Brytanią mające na celu rozwiązanie spornych kwestii. Jest to data optymistyczna ponieważ, niektóre rozwiązania będą prawdopodobnie tymczasowe, szczególnie te dotyczące stacjonowania wojsk Brytyjskich. Jednak nawet ekspert wybrany przez rząd Londynie profesor James Crawford z Uniwersytetu Cambridge uważa tę datę za „realną" do spełnienia (www.scotland.gov.uk: 2013-07-29).

Reasumując, Szkocja i Zjednoczone Królestwo łączy wiele elementów takich jak: wspólna historia, kultura, wojskowość, finanse, ekonomia oraz monarcha. Kluczem do niepodległości będą złoża ropy leżące na dnie Morza Północnego blisko Szkocji. Jeśli Szkoci zagłosują za niepodległością Szkocji, to rząd Alexa Salmonda będzie musiał wynegocjować jak największą część tych złóż dla Szkocji. Należy jednak pamiętać, że póki co większość Szkotów chce tylko zwiększenia kompetencji parlamentu, a nie niepodległości Szkocji. Dlatego, też na obecną chwilę szanse wyjścia Szkocji z Wielkiej Brytanii są małe. Jest bardzo prawdopodobne, że może się powtórzyć scenariusz z referendum odbytego w Qubecu z 1995 roku, które skończyło się na niekorzyść zwolenników secesji po minimalnej przegranej. Jednak na obecną chwilę sytuacja jest bardzo niekorzystna dla zwolenników odejścia Szkocji z Wielkiej Brytanii i tylko poważny kryzys (jak na przykład kryzys w Unii Europejskiej) mógłby wpłynąć na opinię publiczną. Ponadto Alex Salmond nie wyjaśnił jeszcze wielu kwestii jeśli chodzi o przyszłość w pełni niezależnej Szkocji. Czas pokaże, czy Szkocja tylko poszerzy kompetencje swojego parlamentu, czy też opowie się za pełną niepodległością swojego kraju wobec Wielkiej Brytanii.

\section{Bibliografia}

BBC NEWS. (http//www.bbc.co.uk/news/uk-scotland-13326310). Carrell, Serverin. "Oil Set to Become Battleground in Scottish Independence Referendum". The Guardian. Februrary 2012. http://www.theguardian.com/politics/2012/feb/01/scottish-independencenorth-sea-oil, dostęp 28.04.2013).

Currency Choices for an Independent Scotland: Response to the Fiscal Commission Working Group. April 2013. (http://www.scotland.gov.uk/Resource/0042/00420804.pdf, dostęp 11.08.2013).

First Minister's Speech at the Public Discussion Shetland. July 2013._(https://soundcloud. com/scotgov/public-discussion-shetland, dostęp 28.07.2013).

Goodhart, Charles. An Independent Scotland's Choice of Sterling, the Euro or a Separate Currency Will Have Huge Fiscal Impact on a Fledgling Nation. The Scotsman. March 2013. (http://www.scotsman.com/news/scottish-independence-banking-on-currency-union1-2837783, dostęp 29.07.2013).

Maximising the Return from Oil and Gas in an Independent Scotland. July 2013. (http://www.scotland.gov.uk/Resource/0042/00428074.pdf, dostęp 20.07.2013). 
Osborne Warns of Currency Risks for Independent Scotland. April 2013. (http:// www.theguardian.com/politics/video/2013/apr/23/osborne-currency-independentscotland-video, dostęp 20.08.2013).

Phillips, Melanie. The Only way to save the Union is to stop throwing cash at the Scots - and Treat Them as Equal. Dailymain. January 2012. (http://www.dailymail.co.uk/ debate/article-2087122/Scottish-independence-The-way-save-Union-stop-throwingcash-Scots.html, dostęp 28.07.2013).

Polemi.co.uk. (http://polemi.co.uk/informacje/wiadomosci/kwestia-niepodleglosci-szkocjireferendum-niepodleglosciowe-5281, dostęp 11.04.2013).

Salmond, Alex. Scotland as a Good Global Citizen. The Scottish Government. April 2013, (http://www.scotland.gov.uk/News/Speeches/scotland-global-citzen, dostęp 29.07.2013).

Scottish Referendum. (http://www.scotreferendum.com/, dostęp 10.08.2013)

The Guardian. (http://www.guardian.co.uk/politics/scottish-independence-essential-guide, dostęp 28.07.2013).

Trevelyan, G.M. History of England. London: Longman Ltd, 1973.

Zis, Henryk. Historia Anglii. Wrocław: Ossolineum, 2009.

\section{Scotland's Political Choice: Yes or No to Independence?}

\section{Summary}

In his work the author presents the relations between Scotland and England. He tries to explain how Alex Salmond's party NSP (National Scottish Party) gained majority in Scottish Parliament. The essay focuses around some issues that can be decisive for Scotland's future in the United Kingdom, such as economic, political, social and historical aspects. What is more the author tries to predict possible consequences of Scotland's secession. What currency would Scotland choose? How would Scottish people secure their economic prosperity? And last but not least, would Scotland have to reapply to different international organizations like NATO or the EU? The author analyzes David Cameron and Alex Salmond's speeches to show their main arguments for or against the Scottish independence. 